\title{
THE ROLE OF SELECTED INTERNATIONAL DONOR AGENCIES IN THE DEVELOPMENT OF NIGERIA
}

\author{
https://doi.org/10.47743/jopafl-2021-22-14
}

\author{
Michael ENAHORO \\ Department of Political Science, \\ Faculty of the Social Sciences, Delta State University \\ Abraka, Nigeria \\ excellentworldfoundation@yahoo.com
}

\begin{abstract}
The study examined the role of selected international donor agencies in the development of Delta and Edo States. Since the colonial era, some policies and programmes within national development plans have been formulated to address the peculiarities of the region; minority status, agitations and perceived marginalization of the people of the Niger Delta, while the general objective of the study was to examined the role of selected international donor agencies in the development of the Niger Delta Region with a focus on Delta and Edo States. The study adopted the ex-post facto research design. Data were acquired by administering questionnaire among the residents of study area using random sampling method and descriptive statistics was used to explain the frequencies of variables being expressed in percentages The findings of the study revealed that identified corruption and bad governance, political and ethnic interest in developmental projects, climatic factors, poor infrastructural foundations and the expanding insecurity as critical developmental challenges affecting the survival of projects and programmes in the oil producing states. Some recommendations were made: International donor agencies should intensify more effort to formulate policies and programmes to address developmental challenges in Delta and Edo States; International donor agencies should design programme to broaden the knowledge of leaders in the states; Delta and Edo states government should give the international donor agencies free hand to work and execute projects in the states; execution and citing of project should not be based on political influence, donor interest, but driven out of the crucial needs of the people.
\end{abstract}

Keywords: International donor agencies, development, political influence, Niger Delta Region

\section{Introduction}

The unique characteristics of Delta and Edo States in the Niger Delta region make special development efforts imperative. This need was first recommended by the Willink Commission instituted by the British Colonial Government in 1957. The Committee's report gave birth to the Niger Delta Development Board. Although the Commission drew up a programme of action, the political and electoral crises of the first republic, which culminated in the Nigerian Civil War made the board to die a natural death. In the postcivil war military administration, there were controversies about whether or not the board should be resuscitated. What emerged from the controversies was that nothing was done during this era to tackle the Niger Delta unique developmental issue (Akhigbe, 2013). Consequently, the agitations by the people of the region continued; this time accentuated by the increasing exploitation of oil and gas, their increasing profile in the revenue of the nation and the adverse effects on the Niger Delta environment. In 1980 the Shagari administration created the Niger Delta Basin Development Authority. The Authority which made no obvious impact on the lives of the people increased their frustrations and gave rise to serious agitations. This time, the exploration of oil had commenced on a very large scale 
with the government earning huge revenue from it. Thus the neglect of the region was becoming very glaring. In response to the growing need for development, the Shagari administration established the Presidential Task Force, mainly due to the protracted legal battles between the Nigerian Federal Government and the Government of the defunct Bendel State (now Delta and Edo states), which prevented the disbursement of the 1.5 percent approved for the rehabilitation of the oil producing states, the Task Force was highly incapacitated all through its existence (Suberu, 1992).

Delta and Edo states are two among the nine states located in the Niger Delta region. Both States occupy a surface area of about 23, 201 sq.km of the entire 112, 110sq-km of the Niger Delta region. In 2018, the population of this region was estimated to be over 40 million, the overwhelming proportion of which is rural and poor (Kashi \& Watts, 2006). Settlement patterns across the Niger Delta Region including Delta and Edo states have been shaped by the terrain, hydrology and flooding patterns within the massive deltaic basin. Many areas in both Delta and Edo States have developed on islands of drier terrain at the heads of navigable estuaries but in general, the population is predominantly rural. According to the Niger Delta Development Commission (NDDC), the population of the Niger Delta region continues to grow very rapidly3.1 percent per year and is projected to be over 45 million by 2020. The Niger Delta Region has been attractive to major international oil companies including Shell, Chevron, Exxon Mobil, Elf, Agip and Texaco among others that have been involved in joint ventures with the Federal Government in connection with oil exploration, exploitation and production in the area. Links between their operations and human deprivation in the region has raised expectations that the oil companies should contribute to the physical and human development in affected communities Other expectations include the monitoring and promotion of respect for human rights, compliance with environmental standards for exploration and exploitation and where necessary, restitution for damages. Rather the oil companies, particularly Shell Petroleum, have operated for over 30 years without appreciable control or environmental regulation to guide their activities (Akpomuvie, 2011). By and large, the accessible social improvement markers in the Niger Delta locale highlight the shortage of foundation and social administrations, from water to broadcast communications. The recorded disregard of the district's advancement represents a precarious hindrance to accomplishing financial change and destitution mitigation around there (UNDP, 2006). Information from the Federal Office of Statistics, presently the National Bureau of Statistics, uncovered that water in most of the Niger Delta States, come from hazardous inventory offices including; streams, lakes or lakes, unprotected wells and drill openings. The Bureau classifies available sources of potable water for household consumption as; pipe borne, untreated pipe borehole, protected well, river/lake/pond, vendor trucks and other categories. The advent of development commission by Delta and Edo States namely Delta State Oil Producing Areas Development Commission (DESOPADEC) and Edo State Oil and Gas Producing Areas Development Commission (EDSOGPADEC) respectively have yielded little or no effort.

A significant objective of foreign, otherwise referred to as international donors intervention in developing countries is the promotion of economic development and welfare, usually measured by its impact on economic growth and development. (Audretsch \& Feldman 2016) said the premise that African countries are poor and cannot be developed without external intervention from the developed West has brought about the involvement 
of both bilateral and multilateral donor agencies in the development process of many African countries. The interventions have mainly being in form of the injection of capital into certain sectors of the economies of African states. However, some donor partners have also intervened directly in certain programmes and projects in the developing countries, thereby completing government efforts in the development process Umaru, (2012). Amsden (1997) maintained that, after the Nigerian independence in 1960, many bilateral and multilateral donor partners have responded to the development needs of the country by way of intervening in developmental programmes and projects. Anam, (2014) argued that, the micro-project programmes (MPP6) as a poverty alleviation strategy initiative has raised people's productivity and creativity and enhanced entrepreneurship and technological advancement. In addition, it plays a very crucial role in securing economic and social progress and improving income distribution in Cross River State (Becker, 2008). Also as set out in the Paris Declaration on Aid Effectiveness (OECD, 2005), effective aid requires the mutual commitment that partner countries exercise leadership in developing and implementing national development strategies through broad-based consultative processes and that donors respect country leadership and help strengthen their capacity to exercise it. In promoting the pro-poor growth agenda, donors should focus on assisting partner countries to develop and implement nationally owned poverty reduction strategies suited to the local context through processes that strengthen the social contract in favour of propoor growth. Donors may help to ensure that poverty reduction strategies better integrate pro-poor growth with progress on other dimensions of poverty. Support for these policy processes should form the basis of policy dialogue between donors and partner country governments. The outcomes of the policy making process and the policy dialogue should, in turn, be reflected in donors' country assistance strategies and the design of programmes, helping to make them better aligned and more relevant to country-led processes OECD (2007). This study will thus examine the role of international donor partners in the development of Delta and Edo States

\section{Statement of the Problem}

The Niger Delta today is a position of disappointed assumptions and profound established question where extraordinary anxiety now and again ejects in brutality. Long periods of disregard and struggle have encouraged an attack mindset, particularly among the young people who feel they are sentenced to a future without expectation and consider struggle to be a technique to get away from hardship. Industrious clash while to some extent, a reaction to helpless human improvement has likewise dug in it, in this way filling in as a predictable drag on the locale's monetary exhibition and assumptions for headway. Outrageous neediness has been an essential element of the financial advancement of the Niger Delta since the mid 1970s. This is particularly so for the rustic populaces whose profitability has gotten dynamically undermined due fundamentally to natural contamination (Timi, 2016). The income that gathers from oil deals goes to the administrations, thus the public authority bears a significant part of the obligation regarding the natural insurance of the oil delivering regions and the improvement of the way of life for individuals around there. This makes political activity vital to the arrangement of human security and the assurance of the climate of the Niger Delta, the two of which are fundamental to compromise around there. The job of government during the time spent 
tracking down an enduring answer for the ecological decimation of the Niger Delta is a perplexing one, considering the way that an administration organization, the Nigerian National Petroleum Corporation (NNPC), capacities as a joint endeavor accomplice to the oil delivering organizations in Nigeria. The NNPC and its auxiliaries address government interest and gather its rents in the creation and offer of oil and gas. In this way, the ecological peril that oil creation presents regularly comes against the interest of government (Ukaogo, 2008). Further hazardously, this irreconcilable situation is set against the foundation of a culture of debasement that has portrayed public life in Nigeria, particularly the oil area (Falola and Heaton 2008). It is for the most part realized that the oil creating organizations in Nigeria don't meet the fundamental worldwide laws expected of offices directing oil investigation and abuse. This is obviously demonstrated by the unnecessary level of gas erupted during the time spent oil misuse. Neither do the oil organizations have the ability to forestall or deal with the various instances of oil spillage. More often than not, the little that is harmed the climate following an oil slick is attempted solely after vicious fights by nearby networks. The Nigerian government has similarly exhibited an absence of will to force consistence with the principles in light of its own advantages. It is just somewhat recently or with the goal that conclusive advances have started to be taken to ensure the climate. Indeed, even such activity was just motivated after monstrous vicious activity taken by individuals of the Niger Delta locale to force the public authority to react, and the reaction has yielded just unobtrusive outcomes.

While worldwide giver accomplices have as of late entered to aid the formative difficulties in the Niger Delta locale, their job and accomplishment has not come without some type of reactions, regardless of what is by all accounts a certifiable endeavors on paper to help and advance improvement in the Niger Delta area, such exertion has been seen as another interventionist methodology that tries to additional revered the reliance circle to which most agricultural nations has come to relate all global advancement aide programs. Many have contended that the majority of the global oil organizations that is blamable for the formative troubles of individuals of the Niger Delta area are likewise from the parent nations of most benefactor offices who has come to go about as a holy person' or 'savior' for the neediness stricken individuals of the Niger Delta district. The tangible logical inconsistencies has put paid to the genuine state or intensions of worldwide giver offices in the advancement of the Niger Delta area. Yet, one can't totally excuse the endeavors of some global giver offices dependent on some noticeable proof of their exercises regarding advancement in the space of limit building, local area improvement activities, arrangement of fundamental necessities and so forth However, most intercession of these contributors are of their own advantages, instead of individuals they claim to help. It is against this setting that this investigation analyzed the job of chosen worldwide benefactor organizations in the advancement of chose states in the Niger Delta locale with an emphasis on Delta and Edo states.

\section{Objectives of the Study}

The general objective of the study was to examine the role of selected international donor agencies in the development of the Niger Delta Region with a focus on Delta and Edo states. The specific objectives are to: 
i. Explore the development challenges of Delta and Edo States as oil producing States.

ii. Examine the development focus, rationale and objectives of international donor agencies in the development of Delta and Edo States.

iii. Evaluate the impact of the development goals of international donor agencies in the development of Delta and Edo States.

iv. Identify and discuss the challenges confronting international donor agencies in promoting development/achieving developmental goals in Delta and Edo States.

\section{Hypotheses}

The following research hypotheses were stated and tested in the study

HO1: There is no significant relationship between poor developmental focus and development in Delta and Edo States.

HO2: There is no significant difference between what constitute the development focus, rationale and objectives of international donor agencies in the development of Delta and Edo States

HO3: There is no significant relationship between volatile nature of the environment and ability of international donor agencies to promote development in Delta and Edo States. HO4: There is no significant relationship between politicization of aid programme and ability of international donor agencies to promote development in Delta and Edo States.

\section{Literature Review}

The question of what help means for practical development and improvement in agricultural nations has been fervently bantered in the course of the most recent twenty years. This has prompted observational assessments of the guide development relationship. Nonetheless, there is still minimal observational writing on unfamiliar guide - the narrative of development. While a few examinations discover no impacts, different discoveries show a positive and solid relationship and others have discovered negative connection among help and financial development. Among contemplates that discover positive and adverse consequences of unfamiliar guide on monetary development in beneficiary economies, are those which determine its restrictive and unrestricted impacts on advancement. Studies that state an adverse consequence of help on advancement refers to, in addition to other things that guide is driven by geo-political inspirations as opposed to by selfless endeavours. All things considered, regardless of the substantial analysis on advancement help, the upgrades help has caused in the arrangement of foundation, wellbeing offices, training, disinfection, and the profitability of farming are evident (Arndt, Jones, and Tarp, 2007; Sachs, 2014). A few endeavours have been made to clarify the noticed dissimilarity in the guide development writing (See Clemens, Radelet, Bhavnani and Bazzi, 2011).

The powerful examination by Burnside and Dollar (2000), a preliminary in the contingent strand of writing on the guide development relationship, find that guide causes development just in nations that keep up low expansion, are available to exchange, has a changed monetary area and run low spending deficiencies. Some different examinations distinguished conditionalities to the guide development relationship, noticing that the viability of help is contingent on the presence of fare value stuns (Collier and Dehn, 2001), environment stuns just as instability in the terms of exchange (Guillaumont and Chauvet, 
2001), financial strategy and institutional quality (Collier and Dollar, 2002; Heckelman and Knack, 2008), extremist government (Islam, 2003), institutional quality (Burnside and Dollar, 2004), arrangement and government assistance (Collier and Hoeffler, 2004).

Then again, the works of Easterly (2003), Easterly, Levine and Roodman (2004) and Roodman (2007) cast defamation on the contingent strand, focusing on that the meaning of connection impacts in such investigations might be an after effect of augmentations in dataset just as persuasive perceptions. Different investigations look at the unlimited impacts of help on improvement. By and large, these investigations place that the powerlessness to arrange a constructive outcome of help on development can be credited to determination issues and period considered. Noticing the chance of positive just as consistent losses, the greater part of such examinations inspect nonlinearity in the guide development relationship. For example, Hadjimichael, Ghura, Muhleisen, Nord, and Ucer (1995) discover a fundamentally certain effect of help with unavoidable losses in a summed up least squares cross segment of 31 African nations, over the time frame 1986-1992. Other remarkable examinations incorporate those of Hansen and Tarp (2000), Lensink and Morrissey (2000), Dalgaard and Hansen (2001), Hansen and Tarp (2001), Lensink and White (2001), Clements, Gupta, Pivovarsky, and Tiongson (2004), Dalgaard. Hansen and Tarp (2004), Moreira (2005), Werker, Ahmed and Cohen (2009) entomb alia.

Lensink and Morrissey (2000) incorporated a union term in their relapses on a cross part of 75 nations and discover an emphatically huge, positive, direct connection among help and development. In any case, the investigation further contended that vulnerabilities encompassing the size and timing of help could contrarily affect on venture and financial development. Utilizing a recognizable proof technique which inclines toward the constancy of help and the shortfall of direct consequences for current development from slacked help, Hansen, and Tarp (2001) tracked down a solid, non-straight effect of instrumented help development that isn't dependent upon compelling perceptions. The examination by Lensink and White (2001), with the utilization of a two-stage least square assessor, affirms the non-direct effect of help on development in an example of 111 nations over the time frame 1975-1992. Essentially, in relapses instrumented with slacked help streams, Clements et al. (2004) track down a positive, unrestricted, nonlinear, causal connection among help and development. Despite the fact that, Dalgaard et al. (2004) perceived the huge connection between unfamiliar guide and part of land in the jungles, the examination tracked down an unlimited positive and nonlinear impact of help without the collaboration (Clemens et al., 2011). Moreira (2005), utilizing differenced GMM assessors for year 1998, discover a profoundly huge, positive, and non-direct effect of help in 48 nations.

The gathering of studies which discovered no connection for the development help examination actually proposed a reconsidering in the authority advancement help worldview. As per Boone (1996) improvement help has no impact on venture, development, and advancement results, making the minimal affinity to devour help unimportant and minor inclination to contribute zero. At the point when exceptions (compelling perceptions) are taken out from information tests, help will in general no affect development (Dalgaard and Hansen, 2001; Dalgaard et al., 2004). In the wake of instrumenting for help with the utilization of nation size and political connections to givers, Rajan and Subramanian (2008) additionally settled no-development proof. Also, utilizing a more intricate information to propel crafted by Burnside and Dollar (2000), Easterly et 
al. (2004) find that guide doesn't advance monetary development, great arrangement climate in any case. In any case, it is relevant to take note of that the no-development proof announced in certain investigations as referred to above doesn't suggest that, with sound strategy and institutional changes, beneficiary nations can't have a positive guide development experience (See Barro, 1991; Ayodele, Cudjoe, Nolutshungu, and Sunwabe, 2005).

Among contemplates that feature the adverse consequences of unfamiliar guide on development, there are contentions for its Dutch infection impact, 2 effect on debasement, hosing impact on nature of establishments and administration, in beneficiary nations. There are likewise sees on the unavoidable losses of help on advancement by creators who place that there is a limit of help GDP proportion past which help may dial down viability. In this way, help streams are noted to expand help reliance and diminish government drive for homegrown asset activation. As indicated by Moss, Peterson and Van de Walle (2006), enormous and supported guide streams will in general effectsly affect the nature of establishments in low pay nations. Along these lines, unfamiliar guide will in general block financial development in nations with feeble foundations, poor money related strategies, high paces of debasement, awful administration or hose the viability of help to nonindustrial nations (World Bank, 1998; Svensson, 1999). Help viability for producing financial advancement in low pay nations is contingent on acceptable arrangements just as very much planned and carried out guide programs (Burnside and Dollar, 1997, 2000; Radelet, 2006).

The examination by Clemens et al. (2011), which featured the significance of the kind and timing of help, show that guide impacts monetary development offering belief to the pretended by country explicit factors just as nature of the guide projects. Besides, multilateral guide is distributed generally for great arrangement conditions, despite the fact that two-sided help isn't really so allotted (Duc, 2006). Unfamiliar guide likewise impacts on sectoral intensity (Rajan and Subramanian, 2005; Feeny and Ouattara, 2009; Selaya and Thiele, 2010). While most investigations center on explicit area impacts, Selaya and Thiele (2010) discovered the impact of help on development rates at the total level just as its disaggregated consequences for the tradable and non-tradable areas. Amidt, Jones and Tarp (2007) concurred that the development in private and unfamiliar speculation has prompted important administration and financial control issues. Burnside and Dollar (1997) found that there exists a connection between unfamiliar help and financial improvement just when there are exacting guidelines at a fitting time and in a grounded strategy climate. Implying that where there is the presence of good monetary approaches unfamiliar guide will affect on financial turn of events (Collier and Dollar, 2000).

Whitaker (2006) discoveries showed that the way that enormous measures of unfamiliar guide has been sent by created countries and worldwide establishments yet there has been seen absence of result from this brings up the issue regarding the genuine viability of unfamiliar guide to less created country. The investigation had the option to confirm that unfamiliar guide had a constructive outcome yet factors like struggle and topography reduces the effect and can even make it negative. It was proposed by the Arellano, Buliø, Lane and Lipschitz (2009) that expanding unfamiliar guide streams by $\$ 10$ billion would lift around 25 million individuals out of neediness each year, given that such nations have sound financial administration. Djankov (2008) believed that unfamiliar help has a critical adverse consequence on the progressions in political establishments all the more explicitly 
majority rules system. Besides, the OECD (1985) inspected 25 years of ODA and it found that notwithstanding difficulties in Sub-Saharan Africa and a few nations of Latin America, many non-industrial nations had accomplished momentous financial and social development over the past 25 years. It likewise found that guide, joined by developing fares to OECD nations, had fundamentally added to these additions. Conchesta (2008) utilized a solitary condition model to look at the effect of unfamiliar guide on financial development in Tanzania over the time frame 1990 to 2004. In his examination, while unfamiliar guide was disaggregated as far as government advancement uses and repetitive uses other joined factors incorporate net public investment funds, trade development and absolute obligation administration. The examination uncovers that unfamiliar guide and all out obligation administration adversely affect GDP development for the instance of Tanzania.

As per Riddell (2007), Aid tying which is related to project help causes the abuse of the agricultural nations since they are typically obliged to buy things from the contributor country. Unfamiliar guide is additionally liable to prompt the enthusiasm for the genuine conversion scale of the agricultural nations and this outcome into rising homegrown expansion. This is known to be the Dutch illness whereby an inflow of unfamiliar trade in type of fare profit, private capital inflows or unfamiliar guide squeezes the genuine swapping scale of the beneficiary agricultural nation. Unfamiliar guide may prompt the enthusiasm for the conversion scale of the beneficiary nation subsequently lessening the seriousness of the fare area. Fasanya \& Onakoya (2012) analysed the impact of unfamiliar guide on Nigerian financial development during the time of 1970-2010. The exact investigation lays on the neo-old style demonstrating insightful structure and joined a few methodology in current econometric examination/assessment strategies. Their discoveries show that guide streams fundamentally affect monetary development in Nigeria: homegrown venture expanded because of help streams and populace development has no huge impact on guide streams. Subhayu, Sajal and Javed (2013) analyzed the impacts of ODA awards, concessional ODA credits, and private seaward bank advances on development paces of 131 agricultural countries more than 1996-2010 in a brought together manner. Their outcomes show a non-linearity in every one of the three connections, recommending that at low (undeniable) levels awards are better (more regrettable) than credits (concessional or private).

Burnside and Dollar (2000) in their examination of the connection between unfamiliar guide, financial approach, and development of per capital GDP found that guide decidedly affects development in agricultural nations with great financial, money related and exchange arrangements yet with little impact within the sight of helpless strategies. There are different investigations that show no significant relationship among help and development. Easterly (2005) discovered various outcomes when they added more information and expanded the year range from 1993 to 1997. Despite the fact that they don't really contend that guide is insufficient, they store that with the presentation of the new information, the positive connection among help and development wilts away. Okon (2012) attempted to take a gander at a drawn out viewpoint on advancement help and human improvement in Nigeria. The investigation utilizes two phase least squares assessment to breaking down information from 1960 to 2010. The outcome shows that there is a negative connection between advancement help and human turn of events, inferring that guide will in general deteriorate human improvement in Nigeria. 
Chenery and Strout (1966) embracing experimental information from less created nations show that unfamiliar guide has a huge constructive outcome on the beneficiary country monetary development. Different analysts anyway have disturbed this, discoveries that undoubtedly unfamiliar guide adversely affects financial development of nonindustrial nations as it contrarily influences monetary development by supplanting the nearby investment funds (Griffin, 1970; Leff, 1969). The fundamental contention is that unfamiliar guide in its adverse consequence counterbalances the upsides of moving assets and that it sabotages or debilitates administration by expanding the re-visitation of debasement or expansion in loaning for the agricultural nations. Bakare (2011), analyzed the degree of the effect of unfamiliar guide on financial development in Nigeria by utilizing standard measurable strategy, Vector Autoregressive Model (VAR) to decide the wellsprings of stun to development in Nigeria and regarded unfamiliar guide as an endogenous variable. The investigation tracked down a negative connection between unfamiliar guide and yield development, which suggest that unfamiliar guide will in general demolish yield development in Nigeria as opposed to improving it. Mahmoud (2014) analyzed the Impact of Foreign Aid in Economic Development of non-industrial nations: an instance of Philippines Using FDI, GDP and ODA as intermediaries. His examination tracked down a positive effect among the factors contemplated. In any case, this examination is not the same as those audited on the grounds that it receives reciprocal guide as intermediary for unfamiliar guide while Human advancement record are intermediary for financial turn of events. The examination is from 2003 to 2015.

The topic of what help means for supported development and improvement in nonindustrial nations has been the subject of warmed scholarly discussion in the course of recent many years. This has prompted experimental assessments of the guide development relationship. Nonetheless, the observational writing stays uncertain regarding the unfamiliar guide - development story. While a few examinations discover no impacts, different discoveries show a positive and solid relationship and others have discovered negative connection among help and monetary development. Among contemplates that discover positive and adverse consequences of unfamiliar guide on monetary development in beneficiary economies, are those which indicate its restrictive and unequivocal impacts on advancement. Studies that affirm an adverse consequence of help on improvement refers to, in addition to other things that guide is driven by geo-political inspirations as opposed to by selfless endeavours. By the by, regardless of the substantial analysis on advancement help, the enhancements help has caused in the arrangement of framework, wellbeing offices, schooling, disinfection, and the profitability of farming are certain (Arndt, Jones, and Tarp, 2007; Sachs, 2014). A few endeavours have been made to clarify the noticed dissimilarity in the guide development writing (See Clemens, Radelet, Bhavnani and Bazzi, 2011).

The compelling investigation by Burnside and Dollar (2000), a groundwork in the restrictive strand of writing on the guide development relationship, find that guide causes development just in nations that keep up low expansion, are available to exchange, has a changed monetary area and run low spending deficiencies. Some different investigations distinguished restriction's to the guide development relationship, taking note of that the adequacy of help is contingent on the presence of fare value stuns (Collier and Dehn, 2001), environment stuns just as unpredictability in the terms of exchange (Guillaumont and Chauvet, 2001), financial arrangement and institutional quality (Collier and Dollar, 2002; 
Heckelman and Knack, 2008), extremist government (Islam, 2003), institutional quality (Burnside and Dollar, 2004), approach and government assistance (Collier and Hoeffler, 2004). Alternately, the works of Easterly (2003), Easterly, Levine and Roodman (2004) and Roodman (2007) cast slander on the restrictive strand, focusing on that the meaning of connection impacts in such investigations might be a consequence of expansions in dataset just as compelling perceptions. Different investigations analyze the unequivocal impacts of help on improvement. By and large, these investigations set that the powerlessness to arrange a constructive outcome of help on development can be credited to particular issues and period considered. Taking note of the chance of positive just as consistent losses, the vast majority of such examinations look at nonlinearity in the guide development relationship.

For example, Hadjimichael, Ghura, Muhleisen, Nord, and Ucer (1995) discover a fundamentally certain effect of help with unavoidable losses in a summed up least squares cross segment of 31 African nations, over the time frame 1986-1992. Other remarkable examinations incorporate those of Hansen and Tarp (2000), Lensink and Morrissey (2000), Dalgaard and Hansen (2001), Hansen and Tarp (2001), Lensink and White (2001), Clements, Gupta, Pivovarsky, and Tiongson (2004), Dalgaard. Hansen and Tarp (2004), Moreira (2005), Werker, Ahmed and Cohen (2009) bury alia. Lensink and Morrissey (2000) incorporated a combination term in their relapses on a cross segment of 75 nations and discover an unequivocally critical, positive, straight connection among help and development. Notwithstanding, the examination further contended that vulnerabilities encompassing the size and timing of help could adversely affect on venture and financial development. Utilizing an ID methodology which inclines toward the ingenuity of help and the shortfall of direct consequences for current development from slacked help, Hansen, and Tarp (2001) tracked down a solid, non-straight effect of instrumented help development that isn't dependent upon persuasive perceptions. The examination by Lensink and White (2001), with the utilization of a two-stage least square assessor, affirms the non-direct effect of help on development in an example of 111 nations over the time frame 1975-1992. Also, in relapses instrumented with slacked help streams, Clements et al. (2004) track down a positive, genuine, nonlinear, causal connection among help and development. Despite the fact that, Dalgaard et al. (2004) perceived the huge connection between unfamiliar guide and part of land in the jungles, the investigation tracked down an unrestricted positive and nonlinear impact of help without the cooperation (Clemens et al., 2011). Moreira (2005), utilizing differenced GMM assessors for year 1998, discover a profoundly huge, positive, and non-straight effect of help in 48 nations. The gathering of studies that discovered no relationship for the guide development investigation consistently proposed a re-evaluating in the authority improvement help worldview. As indicated by Boone (1996) improvement help has no impact on speculation, development, and advancement results, making the peripheral affinity to devour help irrelevant and minor inclination to contribute zero. At the point when anomalies (powerful perceptions) are eliminated from information tests, help will in general no affect development (Dalgaard and Hansen, 2001; Dalgaard et al., 2004).

Observational investigations about the connection between unfamiliar guide and monetary development have likewise created conflicting and fairly subtle outcomes. On the significant inquiry of if help adds to advancement, the discussion is comprehensively partitioned into the individuals who trust it hurries improvement and the individuals who 
trust it doesn't. Cassen and Associates (1994), Chenery and Carter (1973), Papanek (1973), Rostow (1960) and Sachs (2005), address one side of the separation that accepts that unfamiliar guide is an important condition for agricultural countries to accomplish takeoff. There are, then again, the individuals who accept that unfamiliar guide has never really devastate the economies it should create, mutilate utilization, lower development rate, deteriorate disparities, incite debasement at the two closures, and so on (Bauer, 1981; Bhagwati, 1970; Boone, 1994, 1996; Dacy, 1975; Griffin and Enos 1970; and Mosley and Hudson, 1984). All the more as of late, there are essayists who are more intrigued by the political and 'world exchange' connotations of unfamiliar guide (Easterly, 2006; Chang, 2007; Moyo, 2009 and Stiglitz, 2002). They accept that, instead of assisting helpless African countries with creating, unfamiliar guide further ruins them.

\section{Methodology}

The study adopts an Expost-facto research design using the mixed methods research approach. This means that quantitative and qualitative sources were utilized. The mixed methods approach was used for the study because the data used for the research comprises of both primary and secondary sources which include questionnaires to survey responses from respondents. The researcher administered questionnaires to individual and institutions in the selected States. These data was then complimented with secondary information obtained from documents, reports and government publications, e.t.c.

\section{Population of the Study}

The study focused on Delta and Edo States in the Niger Delta Region of Nigeria with a projected population of 9,899,000 in 2018 based on the 2006 population census figure. This projection is based on $3.2 \%$ annual growth rate as determined by National Population Commission (NPC), Abuja,(2018).

Table 1 Delta and Edo States Population based on 2006

\begin{tabular}{|c|c|c|}
\hline State & Year & Total population \\
\hline Delta & 2006 & $4,112,445$ \\
\hline Edo & 2006 & $3,233,366$ \\
\hline
\end{tabular}

Source: National Population Commission of Nigeria (web), National Bureau of Statistics (web).

Table 2 Delta and Edo States Population based on 2018 projection

\begin{tabular}{|c|c|c|}
\hline State & Year & Total population \\
\hline Delta & 2018 Projection & $5,663,400$ \\
\hline Edo & 2018 Projection & $4,235,600$ \\
\hline
\end{tabular}

Source: National Population Commission of Nigeria (web), National Bureau of Statistics (web) (2018).

\section{Sample and Sampling Techniques}

A sample of 1000 respondents was used for this study. In selecting the sample size, the researcher adopts the stratified simple random sampling method. This method was used in order to get a representative opinion of the citizens of Delta and Edo States of Nigeria. As such, 50 respondents were randomly selected from 10 local Government Areas each chosen from Delta and Edo states giving a total of 1000. According to Harper (1977) "stratification lessens the possibility of inaccurate assessment" the subjects were randomly 
selected from among the stratified groups of international donor partners' members, civil servants, youth Organizations, community leaders and women groups. 10 persons were randomly selected from each of the 5 group from the 20 Local Government Areas understudy, making a total of 1000 respondents from each local government area. In the observation technique, the researcher would visit most of the project sites of the European Union (EU), World Bank, United Nation Development Programme (UNDP) and Department for International Development (DFID) in Delta and Edo states to see the real things on ground such as signposts of donors' projects, equipment and the photograph of the projects. This offered real assessment of such projects.

\section{Validation and Reliability of Instruments}

In order to enhance the validity and credibility of the questionnaire, five independent readers including my two supervisors in the Faculty of the Social Sciences were given copies of the questionnaire including the hypotheses tested, the research questions and the objectives of the study. To ensure the questionnaire's reliability, the study adopts $10 \%$ of the 1000 sample size amounting to 100 respondents. The test - retest method was used to administer the 100 questionnaires to two groups of respondents at different occasions within a span of 2 weeks interval in Sagbama Local Government Area of Bayelsa State, which was outside the study areas of Delta and Edo States, to justify the neutrality of the test group. The responses of the two groups were tested using the Cronbach Alpha to examine its consistency before embarking on the full scale field work. Below is the table presenting the reliability test result.

Table 3 Pilot Study: Results for Reliability Test

\begin{tabular}{|c|c|c|c|}
\hline Variable & $\begin{array}{c}\text { Items in } \\
\text { Scale }\end{array}$ & Alpha Value & Remarks \\
\hline Promoting Development in Oil Producing States & 5 & 0.8322 & Reliable \\
\hline Oil producing States Developmental Challenges & 5 & 0.8435 & Reliable \\
\hline $\begin{array}{c}\text { Development Focus, Rationale, Goals and } \\
\text { Objectives of International Donor Agencies }\end{array}$ & 5 & 0.8562 & Reliable \\
\hline $\begin{array}{c}\text { Development Challenges Confronting International } \\
\text { Donor Agencies }\end{array}$ & 5 & 0.8456 & Reliable \\
\hline Overall & 20 & 0.8444 & Reliable \\
\hline
\end{tabular}

Source: Fieldwork, 2020

Table 3.3 results present the Alpha values that ranged from approximately 0.8322 (See Pomoting Development in Oil Producing States) to 0.8562 (see Development Focus, Rationale, Goals and Objectives of International Donor Partners) for the different sections of the instrument. The overall reliability coefficient value (all items/sections) is 0.8444 . On this note, the study's research instrument is adjudged as reliable since the different coefficients obtained are more than the minimum threshold of 0.50 .

\section{Method of Data Analysis}

Data from secondary sources were collected as they exist in those sources and used to buttress our discussion where necessary, while the primary data was presented and 
analyzed using descriptive statistics such as tables, percentages and inferential statistics such as correlation coefficient. Correlation analysis is the examination of two or more variables in order to determine the extent to which they are related. As a parametric technique of hypothesis testing, the choice of this statistical tool is based on the fact that, it summarizes not only the degree of relationship, but also the direction whether it is positive, negative or zero correlation. The Pearson's coefficient of correlation represented by the symbol ' $r$ ' was specifically used for this study. The Pearson's product moment correlation according to Sanubi (2011:148) is defined by the formula:

This formula is often shortened and written as:

$$
r_{x y}=\frac{\Sigma(\mathrm{X}-\overline{\mathrm{X}})(\mathrm{Y}-\overline{\mathrm{Y}})}{\sqrt{\Sigma(\mathrm{X}-\overline{\mathrm{X}})^{2}}(\mathrm{Y}-\overline{\mathrm{Y}})^{2}}
$$

This formula is often shortened and written as:

$$
\frac{\Sigma x y}{\sqrt{\Sigma x^{2}} y^{2}}
$$

Where $\mathrm{x}=\Sigma(\mathrm{X}-\overline{\mathrm{X}})=\quad$ sum of deviation of $\mathrm{X}$ variable

$$
\begin{array}{ll}
\mathrm{y} & =\Sigma(\mathrm{Y}-\overline{\mathrm{Y}})=\quad \text { sum of deviation of } \mathrm{Y} \text { variable } \\
\mathrm{x}^{2}=\Sigma(\mathrm{X}-\overline{\mathrm{X}})^{2}= & \text { sum of squared deviation of } \mathrm{X}
\end{array}
$$

variables

variables.

$$
\mathrm{y}^{2}=\quad \Sigma(\mathrm{Y}-\overline{\mathrm{Y}})^{2}=\quad \text { sum of squared deviation of } \mathrm{Y}
$$$$
\begin{aligned}
& \mathrm{X}=\text { independent variable } \\
& \mathrm{Y}=\text { dependent variable }
\end{aligned}
$$

Where $\mathrm{x} \quad=\quad=\quad$ sum of deviation of $\mathrm{X}$ variable

$\begin{array}{llll}\mathrm{y} & = & = & \text { sum of deviation of } \mathrm{Y} \text { variable } \\ \mathrm{x} 2 & = & = & \text { sum of squared deviation of } \mathrm{X} \text { variables } \\ \mathrm{y} 2 & = & & \text { sum of squared deviation of } \mathrm{Y} \text { variables. }\end{array}$

$\mathrm{X}=$ independent variable

$\mathrm{Y}=$ dependent variable

Specifically, hypotheses 1, 3 and 4 were tested using the Pearson Correlation Coefficient. Hypothesis 2 was tested using Independent T-test of equality of mean. However, the statistical package for the social sciences (SPSS 20.0) was used to compute and analyze the data that were obtained in determining the correlation coefficient.

\section{Results}

Table 4 Respondents' Demographic Information from Delta and Edo States

\begin{tabular}{|c|c|c|c|c|}
\hline S/N & Variables & Category & Frequency & Percentage \\
\hline 1 & Gender of Respondents & Male & 427 & 54.5 \\
& & Female & 356 & 45.5 \\
& Age of Respondents & $18-25$ years & $\mathbf{7 8 3}$ & $\mathbf{1 0 0 . 0}$ \\
\hline 2 & & $26-30$ years & 127 & 12.5 \\
& & $31-35$ years & 143 & 16.2 \\
& & & 18.2 \\
\hline
\end{tabular}




\begin{tabular}{|c|c|c|c|c|}
\hline & & $36-40$ years & 154 & 19.7 \\
& & $41-45$ years & 139 & 17.8 \\
& & Above 45 years & 122 & 15.6 \\
\hline 3 & Marital Status of Respondents & Total & $\mathbf{7 8 3}$ & $\mathbf{1 0 0 . 0}$ \\
& & Single & 72 & 9.2 \\
& & Married & 467 & 59.6 \\
& & Divorced & 58 & 7.4 \\
& & Widowed & 186 & 23.8 \\
\hline 4 & Educational Qualification of & Total & $\mathbf{7 8 3}$ & $\mathbf{1 0 0 . 0}$ \\
& Respondents & SSCE & 66 & 8.4 \\
& & OND/NCE & 181 & 23.1 \\
& & B.Sc./HND/B.Ed & 328 & 41.9 \\
& & M.Sc./MBA/Ph.D & 208 & 26.6 \\
& & Total & $\mathbf{7 8 3}$ & $\mathbf{1 0 0 . 0}$ \\
\hline 5 & Respondents years of residing in & $1-5$ years & 134 & 17.1 \\
& Delta and Edo States & $6-10$ years & 146 & 18.6 \\
& & $11-15$ years & 169 & 21.7 \\
& & $16-20$ years & 156 & 19.9 \\
& & Above 20 years & 178 & 22.7 \\
& & Total & $\mathbf{7 8 3}$ & $\mathbf{1 0 0 . 0}$ \\
\hline
\end{tabular}

Source: Researcher's Fieldwork, 2020

Gender of Respondents: The table above shows that majority of the respondents are male, which are 427 in number making it a total of $54.5 \%$ of the respondents. Female respondents were 356, which consisting 45.5\%.

Age of Respondents: Age group of 36 - 40 years which comprised of 154 (19.7\%) accounted for the majority of the respondents. The remaining respondents which fell into age bracket of 31 - 35 years, 41 - 45 years, 26 - 30 years, above 45 years and 18 - 25 years accounted for 143 (18.2\%) 139 (17.8\%) 127 (16.2\%), 122 (15.6\%) and 98 (12.5\%) respectively.

Marital Status of Respondents: Most respondents, representing 467 (59.6\%) are married. 186 respondents are widowed. This group constituted $23.8 \%$ of the entire respondents. Respondents that was single were 72 , representing $9.2 \%$ of the entire respondents, while respondents that have been divorced were 58, which constituted $7.4 \%$ of the total respondents.

Educational Qualification of Respondents: The majority of the respondents were B.Sc./HND/B.Ed. holders. These respondents accounted for 328 which constituted $41.9 \%$ of the entire respondents. Respondents with M.Sc./MBA/Ph.D degrees were 208 which represent 26.6\%. Those with OND/NCE were 181 constituted 23.1\% of the respondents while SSCE holders were 66, which constituted 8.4\% of the total respondents.

Respondents Years of Residing in Delta and Edo States: Respondents with above 20 years of residing in Delta and Edo States accounted for 178 or $2.7 \%$ of the entire respondents Test of Hypotheses

HO1: There is no significant relationship between oil producing states development challenges and promoting development in Delta and Edo States. 
Table 5 Test of significant relationship between oil producing states development challenges and promoting development in Delta and Edo States

\begin{tabular}{|c|c|c|c|}
\hline \multicolumn{2}{|c|}{} & $\begin{array}{c}\text { Oil producing } \\
\text { States } \\
\text { Developmental } \\
\text { Challenges }\end{array}$ & $\begin{array}{c}\text { Promoting } \\
\text { Development in Oil } \\
\text { Producing States }\end{array}$ \\
\hline \multirow{2}{*}{$\begin{array}{c}\text { Oil producing States } \\
\text { Developmental Challenges }\end{array}$} & Pearson Correlation & 1 & $.818^{* *}$ \\
\cline { 2 - 4 } & Sig. (2-tailed) & & .000 \\
\cline { 2 - 4 } & $\mathrm{N}$ & 783 & 783 \\
\hline $\begin{array}{c}\text { Promoting Development in Oil } \\
\text { Producing States }\end{array}$ & Pearson Correlation & $.818^{* *}$ & 1 \\
\cline { 2 - 4 } & Sig. (2-tailed) & .000 & 783 \\
\cline { 2 - 4 } & $\mathrm{N}$ & 783 & \\
\hline \multicolumn{2}{|c|}{$* *$ Correlation is significant at the 0.01 level (2-tailed). } \\
\hline
\end{tabular}

Source: Fieldwork, 2020

Table 2 shows a test of linear correlation result on the relationship between oil producing states development challenges and promoting development in Delta and Edo States. The result $r$-value of ( $r\{783\} 0.818, p=0.000$ ) reveals that the test is significant and positive. Therefore, the null hypothesis is rejected, revealing that oil producing states development challenges has a positive and significant relationship with what promote development in Delta and Edo States.

HO2: There is no significant difference between what constitute the development focus, rationale and objectives of international donor agencies in the development of Delta and Edo States

Table 6 Test of significant difference between what constitute the development focus, rationale and objectives of international donor agencies in the development of Delta and Edo States

\begin{tabular}{|c|c|c|c|c|c|c|c|c|}
\hline & \multicolumn{2}{|c|}{$\begin{array}{c}\text { Levene's Test } \\
\text { for Equality of } \\
\text { Variances }\end{array}$} & \multicolumn{5}{|c|}{ t-test for Equality of Means } \\
\hline & & $\mathrm{F}$ & Sig. & $\mathrm{T}$ & $\mathrm{df}$ & Sig & $\begin{array}{c}\text { Mean } \\
\text { Diff }\end{array}$ & $\begin{array}{c}\text { Std. Er } \\
\text { D }\end{array}$ \\
\hline \multirow{2}{*}{$\begin{array}{c}\text { Development } \\
\text { Focus, } \\
\text { Rationale, } \\
\text { Goals and } \\
\text { Objectives of } \\
\text { International } \\
\text { Donor Agencies }\end{array}$} & $\begin{array}{c}\text { Equal } \\
\text { variances } \\
\text { assumed }\end{array}$ & 3.117 & .078 & .791 & 781 & .429 & -.04990 & .06312 \\
\hline & $\begin{array}{c}\text { Equal } \\
\text { variances } \\
\text { not } \\
\text { assumed }\end{array}$ & & & .794 & 778.068 & .427 & -.04990 & .06284 \\
\hline
\end{tabular}

Source: Fieldwork, 2020

Table 3 shows a t-test for the equality of mean difference between what constitute the development focus, rationale and objectives of international donor agencies in the development of Delta and Edo States. The t-test value of ( $\{$ 781\}0.791, $\mathrm{p}=0.429)$ reveals that the test of the mean difference is not significant. Therefore, the null hypothesis is accepted, revealing that what constitute the development focus, rationale and objectives of international donor agencies in the development of Delta and Edo States are the same. By implication, the development focus, rationale and objectives of international donor agencies in Delta and Edo State are the same. 
HO3: There is no significant relationship between the development goals and focus of international donor agencies and promoting development in Delta and Edo States.

Table 7 Test of significant relationship between the development goals and focus of international donor agencies and promoting development in Delta and Edo States.

\begin{tabular}{|c|c|c|c|}
\hline & & $\begin{array}{c}\text { Development Focus, } \\
\text { Rationale, Goals and } \\
\text { Objectives of } \\
\text { International Donor } \\
\text { Agencies }\end{array}$ & $\begin{array}{c}\text { Promoting } \\
\text { Development in } \\
\text { Oil Producing } \\
\text { States }\end{array}$ \\
\hline \multirow{3}{*}{$\begin{array}{c}\text { Development Focus, Rationale, } \\
\text { Goals and Objectives of } \\
\text { International Donor Agencies }\end{array}$} & Pearson Correlation & 1 & $.874 * *$ \\
\hline & Sig. (2-tailed) & & .000 \\
\hline & $\mathrm{N}$ & 783 & 783 \\
\hline \multirow{3}{*}{$\begin{array}{l}\text { Promoting Development in Oil } \\
\text { Producing States }\end{array}$} & Pearson Correlation & $.874 * *$ & 1 \\
\hline & Sig. (2-tailed) & .000 & \\
\hline & $\mathrm{N}$ & 783 & 783 \\
\hline
\end{tabular}

Source: Fieldwork, 2020

Table 4 shows a test of linear correlation result on the relationship between the development goals and focus of international donor agencies and promoting development in Delta and Edo States. The result r-value of ( $\{$ 783\}0.874, $\mathrm{p}=0.000)$ reveals that the test is significant and positive. Therefore, the null hypothesis is rejected, revealing that the development goals and focus of international donor agencies has a positive and significant relationship with the extent development is promoted in Delta and Edo States

HO4: There is no significant relationship between the development challenges confronting international donor agencies and promoting development in Delta and Edo States.

Table 8 Test of significant relationship between the development challenges confronting international donor agencies and promoting development in Delta and Edo States.

\begin{tabular}{|c|c|c|c|}
\hline & & $\begin{array}{c}\text { Development } \\
\text { Challenges } \\
\text { Confronting } \\
\text { International } \\
\text { Donor Agencies }\end{array}$ & $\begin{array}{c}\text { Promoting } \\
\text { Development in } \\
\text { Oil Producing } \\
\text { States }\end{array}$ \\
\hline \multirow{3}{*}{$\begin{array}{c}\text { Development Challenges } \\
\text { Confronting International Donor } \\
\text { Agencies }\end{array}$} & Pearson Correlation & 1 & $.838^{* *}$ \\
\hline & Sig. (2-tailed) & & .000 \\
\hline & $\mathrm{N}$ & 783 & 783 \\
\hline \multirow{3}{*}{$\begin{array}{l}\text { Promoting Development in Oil } \\
\text { Producing States }\end{array}$} & Pearson Correlation & $.838^{* *}$ & 1 \\
\hline & Sig. (2-tailed) & .000 & \\
\hline & $\mathrm{N}$ & 783 & 783 \\
\hline
\end{tabular}

Source: Fieldwork, 2020

Table 5 shows a test of linear correlation result on the relationship between the development challenges confronting international donor agencies and promoting development in Delta and Edo States. The result $r$-value of ( $r\{783\} 0.838, p=0.000)$ reveals that the test is significant and positive. Therefore, the null hypothesis is rejected, revealing that the development challenges confronting international donor agencies has a positive 
and significant relationship with the extent development is promoted in Delta and Edo States

\section{Discussion of Findings}

With respect to the first hypothesis of this study, the study found that oil producing states development challenges has a positive and significant relationship with what promote development in Delta and Edo States This finding is consistent with the studies of David (2004); Kenny (2008) and love and Jacob (2008). The findings also agreed with Okoh (2012) study that revealed key challenges of development to be corruption insecurity and environmental challenges. Amongst other things, the detrimental effects of corruption to an economy cannot be overemphasized (Larsson, 2006). On the one hand, aid could generate incentives which perpetuate weak institutions, ease pressure to reform inefficient institutions, fuel high and rising corruption rates as well as aid-dependency, promote inhibitive bureaucracy, all of which impacts negatively on government efficiency and economic growth (Knack and Keefer, 1995; Heller and Gupta, 2002; Bräutigam, 2004; Clements et al., 2004; Harford and Klein, 2005; Moss et al., 2006; Rajan and Subramanian, 2007).

With respect to the second hypothesis of this study, the study found that that what constitute the development focus, rationale and objectives of international donor partners in the development of Delta and Edo States are the same. This is in line with the view of Sachs, (2005), that developing countries have critically challenged the ability of foreign aid in achieving its goals and that economic theories hypothesized that foreign aid is necessary to fill the financing or investment gap in developing countries and hereby lift the countries out of poverty trap. The third hypothesis reveals that the development goals and focus of international donor partners has a positive and significant relationship with the extent development is promoted in Delta and Edo States. This finding validates the work of Doucouliagos and Paldam (2009) and Kosack (2013) who demonstrated, separately that most international donor agencies adopt same template for their developmental programmes across their country of benefactor. The findings also agrees with views of Amidt, Jones and Tarp (2007) that the growth in private and foreign investment has lead to valuable governance and economic development and also supported by the views of Burnside and Dollar (1997) that there exist a link between foreign assistance and economic development. In the same vein a UN Issue Paper (2007) also agreed that Aid has successfully supported poverty reduction and growth promotion in many countries (including Nigeria). Consequently, even if aid flows have not stimulated growth under all circumstances, they have had a positive effect on average.

With respect to the fourth hypothesis of this study, the study found that the development challenges confronting international donor partners has a positive and significant relationship with the extent development is promoted in Delta and Edo States. This finding is in agreement with previous studies conducted by Alesina and Dollar (2000); Beine, Dolquie and Rapoport (2001); Kenny (2008) and Kosack (2013), Akpomuvie (2011) and Oyediran and Nweke (2014). They all reveals that funding is critical to development and most international donor partner rely heavily on other funding partners before they can execute projects. Also, the finding of Missionary International Services News Agency, (2008), indicates that foreign aid is declining day by day. Rich countries have cut aid funds by $8.4 \%$, in consideration of real value and inflation. Some years back, 
the governments of the 22 economies that belong to the OECD donated about EUR 66 billion, which is about $0.28 \%$ of the GDP of the 22 donor countries of the organization; it was $0.31 \%$ of GDP in 2006 . After rising steadily through the 1980 s and peaking at $\$ 60.9$ billion in 1992, development-aid flows declined to $\$ 59.2$ billion by 1994 . Members of the Organization for Economic Cooperation and Development (OECD) committed 0.30 percent of their combined GNP to development aid in 1994, the lowest rate in twenty-one years and less than half the international standard of 0.70 percent (Hook, 1996).

\section{Conclusions}

The study examined the role of selected international donor agencies in the development of Delta and Edo States. From the findings of this study, we concluded that corruption and bad governance, political and ethnic interest in developmental projects, climatic factors, poor infrastructural foundations and the expanding insecurity as critical developmental challenges affecting the survival of projects and programmes in the oil producing states. And that the developments focus of these international donor agencies are the same in Delta and Edo States because their main focus is on alleviating poverty. The study also concluded that development challenges' confronting international donor agencies affect development is promoted in Delta and Edo States.

\section{Recommendations}

Based on the conclusion reached in this study, the following recommendations were made. - $\quad$ International donor agencies should intensify more effort to formulate policies and programmes to address developmental challenges in Delta and Edo States.

- International donor agencies should design programmes to broaden the knowledge of leaders in the states

- $\quad$ Delta and Edo states government should give the international donor agencies free hand to work and execute projects in the states

- $\quad$ Execution and citing of project should not be based on political influence, donor interest, but driven out of the crucial needs of the people

- Government should encourage donor agencies by providing the necessary basic development infrastructures, collaboration and funding for project execution

\section{References}

1. Abasiekong, E . M. (1982). Integrated rural development in the third World: its concepts and problems. In, Ottong, J . G and Bassey, A . O. (2009). Community development: Principles and Practice. Calabar: Index Educational Foundations Publishers.

2. Acemoglu, Daron, Simon Johnson, and James A. Robinson. (2005). Institutions as a fundamental cause of longrun economic growth. In Handbook of Economic Growth. Edited by Philippe Aghion and Steven N. Durlauf.Amsterdam: Elsevier B.V., 1A, 386-472..

3. Acemoglu, V. Johnson, D \& Robinson, C (2010). Assessing Democracy Assistance: Nigeria. The United Nations Democracy Fund.

4. Akhigbe, J. (2013).The State and Development Interventions in the Niger Delta Region of Nigeria. International Journal of Humanities and Social Science, 3(10), 255-263. 
5. Akpomuvie, A. B. (2010). Democracy and Democratic Consolidation in Nigeria's Fourth Republic: Issues and Challenges. IOSR Journal of Humanities and Social Science, 19(10), 05-10.

6. Akpomuvie, O. B. (2011). Breaking Barriers to Transformation of the Niger Delta Region of Nigeria: A Human Development Paradigm. Journal of Sustainable Development, 4(3), 210-222.

7. Alesina, K \& Dollar, B. (2000). Foreign Democratic Assistance to Nigeria (1999-201): The Nexus Between Strategy and Elections Results. Global Journal of Political Science and Administration, 14(1), 29-

37.

8. Amartya, S. (1999). Development as freedom. London. Oxford University Press.

9. Amsden, A. H. (2007). Bringing production back in understanding government's role in late industrialization. World Development, 25 (4), 469-480. https://doi.org/10.1016/S0305-750X(96)00124-6

10. Amsden, F. (1997)). Research Design, Qualitative, Quantitative and Mixed Methods Approaches. London: Sage Publication.

11. Anam, R (2014). A preface to democratic theory. Chicago: University of Chicago Press.

12. Andrews, Matt, Lant Pritchett and Michael Woolcock (2012), "Escaping capability traps through Problem-Driven Iterative Adaptation (PDIA)”, Center for Global Development Working Paper, No. 299,

13. Annen, D \& Knack, S. ( 2015). On the Delegation of Aid Implementation to Multilateral Agencies World Bank Policy Research Working Paper No. 7455.

14. Arndt, C., Jones, S., \& Tarp, F. (2007). Aid and Development: The Mozambican Case. In S. Lahiri (Ed.), Theory and Practice of Foreign Aid, Frontiers of Economics and Globalization (Vol. I). Amsterdam: Elsevier. https://doi.org/10.1016/S1574-8715(06)01014-1

15. Arora, A. \& Athreye, S, (2002). The software industry and India's economic development, Information Economics and Policy, Elsevier,. 14(2), 253-273. https://doi.org/10.1016/S01676245(01)00069-5

16. Arora, L \& Athreye, H/ (2002). An Introduction to Qualitative Research. London: Sage Publication. 17. Arrow, K. (2002). The economic implications of learning by doing. The Review of Economic Studies. 29, 3, 155-173. https://doi.org/10.1007/978-1-349-15430-2_11

18. Atun, T \& Kazatchkine G, (2009). A Companion to Qualitative Research. London: Sage Publication.

19. Audretsch, D. B. \& Feldman, M. P. (2006). R. the geography of innovation and production. American Economic Review, 86 (3), 630-640. DOI https://doi.org/10.1057/978-1-349-94848-2 537-1

20. Ayodele, T., Cudjoe, F., Nolutshungu, T. A., \& Sunwabe, C. K. (2005, September 14). African Perspectives on Aid: Foreign Assistance Will Not Pull Africa Out of Poverty. Economic Bulletin \#2, pp. Available at: http://www.cato.org/publications/economic-development-bulletin/african-perspectives-aidforeign-assistance-will-not-pull-africa-out-poverty.

21. Bakare, A. S. (2011). The Macroeconomic Impact of Foreign Aid in sub-Saharan Africa: The Case of Nigeria. Business and Management Review. 1(5). 24032.

22. Banerjee, A. \& Iyer, L. (2005). History, Institutions, and Economic Performance: The Legacy of Colonial Land Tenure Systems in India. The American Economic Review, 95, 4. 1190-1213 DOI: https://doi.org/10.1257/0002828054825574

23. Barro, R. (1991). Economic Growth in a Cross Section of Countries. Quarterly Journal of Economics, 106(2), 407-443. https://doi.org/10.2307/2937943

24. Barnes A., Brown G. W. (2011). The idea of partnership within the millennium development goals: Context, instrumentality and the normative demands of partnership. Third World Quarterly ;32:165-180. https://doi.org/10.1080/01436597.2011.543821

25. Bauer, P. T. (1981). Equality, the Third World and Economic Delusion. London: Weidenfeld and Nicholson.

26. Beine, M., Docquie, F. \& Rapoport, H. (2001). Brain drain and economic growth: Theory and evidence. Journal of Development and Economics, 64 (1), 275-289. https://doi.org/10.1016/S03043878(00)00133-4

27. Berthélemy, J. C. \& Tichit, A. (2004). Bilateral donors ${ }^{\text {ee }}$ aid allocation decisions: A threedimensional panel analysis. International Review of Economics and Finance, 13: 253-274. https://doi.org/10.1016/j.iref.2003.11.004

28. Bhagwati, J. N. (1970) Foreign Aid. Hammondsworth, England: Penguin. 
29. Biesma, (2009) Biesma, R.G., Brugha, R., Harmer, A., Walsh, A., Spicer, N. and Walt, G. (2009). 'The effects of global health initiatives on country health systems: A review of the evidence from HIV/AIDS control', Health Policy and Planning 24: 239-52. https://doi.org/10.1093/heapol/czp025

30. Birdsall, N., Kharas, H. J., Mahgoub, A., Perakis, R.. (2010).Quality of Official Development Assistance Assessment. Center for Global Development Washington, DC.

31. Block, F., \& Keller, M. R. (2009). Where do innovations come from? Transformations in the US economy, 1970-2006. Socio-Economic Review, 7(3), 459-483. https://doi.org/10.1093/ser/mwp013

32. Boone,P. (1996). Politics and the effectiveness of foreign aid. European economic review, 40(2), 289-329. https://doi.org/10.1016/0014-2921(95)00127-1

33. Brainard, Lael, Ed. 2007. Security by other means: Foreign assistance, global poverty, and American leadership. Washington, D.C.: Brookings Institution Press.

34. Brautigam, D.A, \& Stephen, K. (2004). Foreign aid, institutions, and governance in sub-Saharan Africa.Economic Development \& Cultural Change 52 (2):255(31). https://doi.org/10.1086/380592

35. Brinkerhoff, D. W., \& Benjamin C. (2002). Managing policy reform: Concepts and tools for decision-makers in developing and transitioning countries. Bloomfield, CT: Kumarian Press. Bueno de Mesquita,

36. $\quad$ Bruce, D.(2003). The logic of political survival. Cambridge, Mass.: MIT Press.

37. Buffardi, A. L., Robinson, C, \& Patricia J. G. (2011). The Chronicles of CONAMUSA: Institutional strategies to overcome shared governance challenges. Paper presentation at the International Studies Association Annual Convention. Montreal, Canada, March 16-19, 2011.

38. Buiter, W. H. (2007). Country ownership: A term whose time has gone. Development in Practice, 17(4-5): 7-652. https://doi.org/10.1080/09614520701469856

39. Burnside, C. \& Dolar, D. (2000). Aid, politics and growth. The American Economic Review, 90, 847-868. https://doi.org/10.1257/aer.90.4.847

40. Burnside, C. \& Dollar, D. (2004). Aid, Policies and Growth: Revisiting Evidence. Policy Research Working Paper 3251. Washington, D.C.: World Bank.

41. Burnside, C., \& Dollar, D. (1997). Aid, Policies and Growth. Policy Research Working Paper 1777, World Bank, Development Research Group, Washington D.C.

42. Burnside, C., \& Dollar, D. (2000). Aid, Policies, and Growth. American Economic Review, 90(4), 847-868. https://doi.org/10.1257/aer.90.4.847

43. Cassen, R. \& Associates (1994). Does Aid Work? Report to an Intergovernmental Task Force. Oxford: Center for Global Development Working Paper No. 39

44. Chambers, R. (2004). Ideas for Development. IDS Working Paper 238. Sussex: IDS.

45. Chambers, R. (2007). Whose reality counts? Putting the first last. London, England: ITDG Publishing.

46. Chang, H. (2007). Bad Samaritans: The Guilty Secrets of Rich Nations and the Threat to Global Prosperity. London: Random House Books.

47. Chenery, H. B. \& Carter, N. G. (1973). Foreign Assistance and Development Performance. American Economic Review 63. https://www.jstor.org/stable/1817109

48. Chenery, H. B. \& Strout, A. M. (1966). Foreign Assistance and Economic Development. American Economic Review. 56(4). https://doi.org/10.1007/978-1-349-15238-4_9

49. Clemens, M., Radelet, S., Bhavnani, R. R., \& Bazzi, S. (2011). Counting Chickens When They Hatch: Timing and the Effects on Aid on Growth. CGD Working Paper 44/2004. Washington, D. C.: Center for Global Development.

50. Clements, B., Gupta, S., Pivovarsky, A., \& Tiongson, E. R. (2004). Foreign Aid: Grants Versus Loans. Finance and Development, 46-49. https://doi.org/10.5089/9781451922530.022

51. Collier, P. (2002). Making aid smart: Institutional incentives facing donor organizations and their implications for aid effectiveness." Washington, DC: World Bank. Collier, Paul, and

52. Collier, P., \& Dehn, J. (2001). Aid, Shocks and Growth . Policy Research Working Paper 2688. World Bank, Washington, D.C.

53. Collier, P., \& Dollar, D. (2002). Aid Allocation and Poverty Reduction. European Economic Review, 45(1), 1-26. https://doi.org/10.1016/S0014-2921(01)00187-8

54. Collier, P., \& Hoeffler, A. (2004). Aid, Policy and Growth in Post-Conflict Societies. European Economic Review, 48(5), 1125-1145. https://doi.org/10.1016/j.euroecorev.2003.11.005 
55. Comptroller and Auditor General (2015) Managing the Official Development Assistance target. London: National Audit Office (January).

56. Congressional Budget Office. (1997). The role of foreign aid in development. Washington, DC: Author.

57. Cowen, M.P \& Shenton, R. (1998). Agrarian doctrines of development: Part I. Pages 49-76 | Published online: 05 Feb 2008

58. Dacy, D. C. (1975). Foreign Aid, Government Consumption, Saving and Growth in LDCs. Economic Journal. September.

59. Daily Times. (2008). Road Map 2020. Lagos: Daily Times Publication.

60. Dalgaard, C., \& Hansen, H. (2001). On Aid, Growth and Good Policies. Journal of Development Studies, 37(6), 17-41.

61. Dalgaard, C.-J., Hansen, H., \& Tarp, F. (2004). On the Empirics of Foreign Aid and Growth. The Economic Journal, 114(496), 196-216. https://doi.org/10.1111/j.1468-0297.2004.00219.x

62. David, D. (2004). Development effectiveness: What have we learnt? Economic Journal 114 (496):F244-F71. https://doi.org/10.1111/j.1468-0297.2004.00221.x

63. Department For International Development, (DFID) Nigeria Operational Plan 2011-2016 (Accessed 20 December 2018)

64. Deverajan, S, \& Vinaya, S. (2000). The implications of foreign aid fungibility for development assistance. Washington, DC: World Bank.

65. DiMaggio, P. J., \&Walter W. P. (1983). The iron cage revisited: Institutional isomorphism and collective rationality in organizational fields. American Sociological Review 48.

66. Djankov, S., (2008). The Curse of Aid. Journal of Economic Growth, 13(3), 169-194. https://doi.org/10.1007/s10887-008-9032-8

67. Doucouliagos, H., \& Paldam, M. (2009). The Aid Effectiveness Literature: The Sad Results of 40 Years of Research. Journal of Economic Surveys 23 (3):433-61. https://doi.org/10.1111/j.14676419.2008.00568.X

68. Duc, V. M. (2006). Foreign Aid and Economic Growth in Developing Countries - A Cross-Country Empirical Analysis. Retrieved from CNX: http://cnx.org/contents/8c8c2f06-c07f-4e32-a37c2936554d0319@2.

69. Dye, C, Geoffrey P. Garnett, K. S, \& Brian G. W. (1998). Prospects for worldwide tuberculosis control under the WHO DOTS strategy. Lancet, 352, 1886-1891. https://doi.org/10.1016/S01406736(98)03199-7

70. $\quad$ Easterly, W (2006).The White Man's Burden. The Penguin Press.

71. Easterly, W. (2003). Can Foreign Aid Buy Growth? Journal of Economic Perspectives, 17(3), 2348. https://doi.org/10.1257/089533003769204344

72. Easterly, W. (2006). White man's Burden: Why the Efforts to Aid the Rest Have Done so Much Ill and so Little Good. London. Penguin Books.

73. Easterly, W. and Pfutze, T. (2008). Where Does the Money Go? Best and Worst Practices in Foreign Aid. Journal of Economic Perspectives22(2).

74. Easterly, W. and Williamson, C. R. (2011). Rhetoric versus Reality: The Best and Worst of Aid Agency Practices. World Development39(11), 1930-1949. https://doi.org/10.1016/j.worlddev.2011.07.027

75. $\quad$ Easterly, W. R.(2008). Reinventing Foreign Aid. Cambridge, Mass.: MIT Press.

76. Easterly, W. R., \& Tobias, P. (2008). Where does the money go? Best and worst practices in foreign aid. Journal of Economic Perspectives. 22 (2):29(4). https://doi.org/10.1257/jep.22.2.29

77. Easterly, W. R., Ross, L, \& David R. (2004). Aid, policies, and growth: comment. American Economic Review. 94 (3):774(7). https://doi.org/10.1257/0002828041464560

78. Easterly, W. (2007). Are Aid Agencies Improving? Economic Policy, 22(52), 633-678. https://doi.org/10.1111/j.1468-0327.2007.00187.x

79. Easterly, W.( 2002). Can Foreign Aid Buy Growth? The Journal of Economic Perspectives. 17,. 3 https://doi.org/10.1257/089533003769204344

80. Easterly, W., Levine, R., \& Roodman, D. (2004). New Data, New Doubts: A Comment on Burnside and Dollar's 'Aid, Policies, and Growth (2000)'. American Economic Review, 94(3), 781-784. https://doi.org/10.3386/w9846 
81. Eichler, R, \& Amanda, G.. (2008). Health systems strengthening via performance-based aid: Creating incentives to perform and to measure results. In Brookings Global Economy and Development working paper series. Washington, DC: Brookings Institution.

82. Eisenhardt, K. M. (1989). Agency theory: An assessment and review.Academy of Management Review.14 :57(18). https://doi.org/10.5465/amr.1989.4279003

83. Entwistle, J.\& Filippo, C. (2005). An operational approach for assessing country ownership of poverty reduction strategies. Volume I: Analysis and implications. Washington, DC: World Bank. Epstein.

84. Entwistle, J., \& Cavassini, F. (2005). An Operational Approach for Assessing Country Ownership of Poverty Reduction Strategies. Volume I: Analysis and Implications. Washington, DC: World Bank.

85. Esrey, S. A. (2001), Health benefits from improvement in water supply and sanitation: Survey and analysis of the literature on selected disease. Technical Report No. 66, Washington D.C.: Water and Sanitation Health Project.

86. Essien, S. F. (2008), Principles of rural development: Readings in cooperative economics and management. Lagos: Computer Edge Publishers.

87. Etekpe, A. (2007). The politics and conflicts over oil and gas in the Niger Delta religion: The Bayelsa state experience. Port Harcourt: Tower Gate Resources.

88. Feachem, G. A., \& Oliver J. S. (2006). An examination of the Global Fund at 5 years. Lancet, 368, 537-540. https://doi.org/10.1016/S0140-6736(06)69163-0

89. Feeny, S., \& Ouattara, B. (2009). What Type of Economic Growth Does Foreign Aid Support? Applied Economic Letters, 16, 727-730. https://doi.org/10.1080/13504850701221832

90. Feldman, M.P. \& Kelley, M.R. (2003). Leveraging Research and Development: Assessing the Impact of the U.S. Advanced Technology Program Small Business Economics 20, 153-165.

91. Fielding, D. J., McGillivray, M\& Sebastian, T. (2006). A wider approach to aid effectiveness: Correlated impacts on health, wealth, fertility and education. Helsinki, Finland: UNU-WIDER Research Paper, 2006/23, 1-16.

92. Foster, M, Adrienne B, \& Tim,C. (2000). Sector-wide approaches for health development: A review of experience. Geneva, Switzerland: WHO.Geneva.United Nations: Convention on Trade and Development. 93. Freeland,N. (2007). Superfluous, Pernicious, Atrocious and Abominable? The Case Against Conditional Cash Transfers”, IDS Bulletin,.38/3, 75-78,

94. Gibson, C., K. Andersson, E. Ostrom, \& S. Shivakumar. (2005). The Samaritan's Dilemma: The Political Economy of Development Aid. New York, NY: Oxford University Press.

95. Gore, C. (2000). The rise and fall of the Washington consensus as a paradigm for developing countries, World Development, 28 (5): 789-80. https://doi.org/10.1016/S0305-750X(99)00160-6

96. Griffin, K. B. and Enos, J. L. (1970). Foreign Assistance: Objectives and Consequences. Economic Development and Cultural Change, Vol.18 April.

97. Grindle, Merilee (2004b), Despite the Odds: The Contentious Politics of Education Reform, Princeton University Press, Princeton and Oxford.

98. Guillaumont, P., \& Chauvet, L. (2001). Aid and Performance: A Reassessment. Journal of Development Studies, 37(6), 66-92. https://doi.org/10.1080/713601083

99. Hadjimichael, M. T., Ghura, D., Muhleisen, M., Nord, R., \& Ucer, E. M. (1995). Sub-Saharan Africa: Growth, Savings, and Investment, 1986-93. Washington, D.C.: International Monetary Fund.

100. Hansen, H., \& Tarp, F. (2000). Aid Effectiveness Disputed. Journal of International Development, 12(3), 375-398. https://doi.org/10.1002/(SICI)1099-1328(200004)12:3<375::AID-JID657>3.0.CO;2-M

101. Hansen, H., \& Tarp, F. (2001). Aid and Growth Regressions. Journal of Development Economics, 64(2), 547-570. https://doi.org/10.1016/S0304-3878(00)00150-4

102. Hassan UM (2000) Role of Foreign Aid: A Critical Analysis. ThaNetional. Kardar, S. (1995) Political Economy of Pakistan. Ferozensons. Lahore

103. Heckelman, J., \& Knack, S. (2008). Foreign Aid and Market-liberalizing Reform. Economica, 75, 542-548. https://doi.org/10.1111/j.1468-0335.2007.00623.x

104. Helen. S. (2009). Towards a global fund for the health MDGs? Lancet, 373, $2110-2111$. https://doi.org/10.1016/S0140-6736(09)61149-1

105. Hickey, S. and Mohan, G. (2003) Relocating Participation within a Radical Politics of Development: Citizenship and Critical Modernism Draft working paper prepared for conference on 'Participation: From Tyranny to ransformation? Exploring new approaches to participation in development', 27-28 February 2003, University of Manchester, Manchester. 
106. Ibaba, E., (2005), Economic revitalization: cases and strategies for city and suburb. Sage Publications, Incorporated.

107. International Development Committee (2009), Eighth Report of Session 2008-09, DFID's Programme in Nigeria, HC 840-I accessed 20 July 2016

108. Islam, M. N. (2003). Political Regimes and the Effects of Foreign Aid on Economic Growth. The Journal of Developing Areas, 37(1), 35-53. https://www.jstor.org/stable/4192937

109. Johnson, O. E. G. (2005). Country ownership of reform programmes and the implications for conditionality. G-24 Discussion Paper Series,. 35.

110. Kanbur, R. (2006) What's Social Policy got to do with Economic Growth? Available at http://www.arts.cornell.edu/poverty/kanbur/

111. Kashi, E \& Watts, M. (2008). Curse of the black gold: 50 years of oil in the Niger Delta. Brooklyn, N.Y.: Power House Books.

112. Kaufmann, D, A, \& Massimo M. (2010). The Worldwide Governance Indicators : A summary of methodology, data and analytical issues. In World Bank Policy Research Working Paper No. 5430 Washington, DC: The World Bank.

113. Kaufmann, D, A, \& Pablo Z. (2000). Governance matters: From measurement to action. Finance and Development, , 10-13. https://doi.org/10.5089/9781451952827.022

114. Kenny, C. (2008). What is effective aid? How would donors allocate it? The European Journal of Development Research 20 (2):330-46. https://doi.org/10.1080/09578810802078704

115. Kharas, H. \& Linn, J.F. (2008). Better Aid: Responding to Gaps in Effectiveness. The Brookings Institution1775 Massachusetts Ave., NW Washington, DC.

116. Knack, S., Rogers, F. H. and Eubank, N. (2011). Aid Quality and Donor Rankings.WorldDevelopment39 (11), 1907-1917., https://doi.org/10.1016/j.worlddev.2011.07.028

117. Koeberle, S, \& ZoranStavreski. (2006). Budget support: Concept and issues. In Stephan Koeberle, ZoranStavreski, and Jan Walliser (Eds), Budget support as more effective aid? Recent experiences and emerging lessons. Washington, DC: World Bank. . 3-28.

118. Kosack, Stephen. 2003. "Effective aid: How democracy allows development aid to improve the quality of life." World Development 31 (1):1-22.World Bank. 2011. https://doi.org/10.1016/S0305750X(02)00177-8

119. Kramarz,T. \& Momani, B. (2013). The World Bank as Knowledge Bank: Analyzing the Limits of a Legitimate Global Knowledge Actor, Review of Policy Research.

120. Krugman, P. (1995) Development, Geography, and Economic Theory, Cambridge MA: MIT Press

121. Leftwich, Adrian (2008), Developmental States, Effective States and Poverty Reduction: The Primacy of Politics, UNRISD (United Nations Research Institute for Social Development), Geneva.

122. Leibenstein, H. (1957) Economic Backwardness and Economic Growth, New York NY: John Wiley.

123. Lensink, R., \& Morrissey, O. (2000). Aid Instability as a Measure of Uncertainty and the Positive Impact of Aid on Growth. Journal of Development Studies, 36(3), 31-49. https://doi.org/10.1080/00220380008422627

124. Lensink, R., \& White, H. (2001). Are There Negative Returns to Aid? Journal of Development Studies, 37(6), 42-65. https://doi.org/10.1080/713601082

125. Lewis, C.( 2009). Culture, executive function, and social understanding. Volume 2009, Issue123 Special Issue: Social Interaction and the Development of Executive Function.

126. Lewis. A, (1982). The social psychology of taxation. Volume21, Issue2.

127. Lipton M, Toye J, \&Cassen R (1986). In R. Cassen (ed.)DoesAidWork?, Oxford: Oxford University Press.

128. Love O. A \& Jacob, O. (2018). Foreign Donor Interventions and Economic Development: Impact Assessment of European Union Micro ProjectProgramme in Nigeria. International Journal of Advanced Research in Public Policy, Social Development and Enterprise Studies | IJARPPSDES3, 1

129. Lucky, O. O. (2017). Democratic Transition and Consolidation in Nigeria: Trends and Prospects since 1999. International Journal of Politics and Good Governance, 8(8), 1-21.

130. Lupu, D. (2019). Financial development and economic growth in Eastern Europe. Journal of Public Administration, Finance and Law, (16), 157-165.

131. Mac-Rae, D. (2012). Need delegation of the European Union. An Address Presented By AMB. Nigeria at the Launching of the MPP works Implementation in Ondo State. EU-MPP, fact sheet (n d). MPP, 
micro - Projects Program in the Nine Niger Delta states, funded by the European Union (EU) in Association with the Federal Government of Nigeria(FGN) Supervised by the national Planning Commission. Retrieved august 2, 2018 from http.//www.Mmp .org. 9

132. Mahajan, V. D. (2012). Political Theory. New Delhi: S. Chand Publishers.

133. Martns , L. (2013). Integrative motivation in a globalizing world. Journal of Multilingual and Multicultural Development 34 (1), 14-29

133. McCord,A. (2013), The Public Pursuit of Secure Welfare: Background Paper on International Development Institutions, Social Protection and Developing Countries,EuropeanCommission,https:/ec.europa.eu/europeaid/sites/devco/files/the-public-pursuit-ofsecure-welfare_en.pdf(accessed on 24April2019)

135. McGranahan, D. (1972). Development indicators and development models. The Journal of Development Studies, Volume 56, Issue 12.

136. Milner, H. V. and Tingley, D. H. (2010). The political economy of US foreign aid: American legislators and the domestic politics of aid. Economics andPolitics, 22: 200-231. https://doi.org/10.1111/j.1468-0343.2009.00356.x

137. Moreira, S. B. (2005). Evaluating the Impact of Foreign Aid on Economic Growth: A Cross-Country Study. Journal of Economic Development, 30(2), 25-48. http://hdl.handle.net/10400.26/4464

138. Mosley, P. and Hudson, J. (1984). Aid, the Public Sector and the Market in LDCS. University of Bath: Papers in Political Economy.

139. Moss, T., Pettersson, G., \& Van de Walle, N. (2006). An Aid-Institutions Paradox? A Review Essay on Aid Dependency and State Building in Sub-Saharan Africa. Center for Global Development, Working Paper 74.

140. Moyo, D. (2009) Dead aid: Why aid is not working and how there is a better way for Africa. London: Penguin Books.

141. National Population Commission of Nigeria (2017), National Bureau of Statistics (web). NDES Report.

142. Nkpoyen, F. \& Bassey, G. E. (2012). Micro-Lending as an empowerment strategy for poverty alleviation among women in Yala Local Government Area of Cross River State,Nigeria, International Journal of Business and Social Science, 32 (18), 233-241.

143. North, D. (2011) "Institutions, institutional change and economic performance", Cambridge university press.

144. OECD (2007). The Role of Donors in Promoting Pro-Poor Growth: Policy Guidance for Donors. OECD Publishing, Paris.

145. OECD (2011) 'What do we know about multilateral aid? The 54 billion dollar question, 1-11' (http://www.oecd.org/development/aid-architecture/13_03_18 Policy Briefing on Multilateral Aid.pdf).

146. Okon, E. D. (2012). Global Partnership / co-operation and pragmatic community development: An assessment of An EU-Micro projects Program (EU-MPP) in selected communities in AkwaIbom State, South -South Nigeria. International Journal of Scientific Research in Education (IJSRE), 5 (3), 171 - 181

147. Okon, E. O. (2012). Five Decades of Development Aid to Nigeria: The Impact on Human Development. Journal of Economics and Sustainable Development, 3(1), 32-42.

148. Oludimu, O. L. (ed) (2004). Revitalizing Ogun State agriculture: OGEGEP II as another milestone. Ogun State employment generation programme No. 3.

149. Ottong, J.E. \& Bassey, A.O. (2009), Community development: Principles and practice. Calabar: Index Educational Foundation Publisher.

150. Oyediran, P. A., \&Nweke, O. I. (2014). An Appraisal of Nigerian Democratic Journey Between 1999-2014. JORIND, 12(2), 54-66.

151. Omoweh, D. (2004). Shell petroleum development company, state and underdevelopment of the Niger delta of Nigeria: a study in Environmental Degradation. Trenton: Africa World Press.

152. Palagashvili, L. and Williamson, C.R. (2014) Ranking Foreign Aid Agency Best Practices: New Donors, New Findings (http://ssrn.com/abstract=2496716).

153. Papanek, G. F. (1973). Aid Foreign Private Investment, Savings and Growth in LDCs. Journal of Political Economy, 81.

154. Parker, S. \& Todd, P. (2017), Conditional Cash Transfers: The Case of Progresa /Oportunidades”, Journal of Economic Literature,.55/3,.866-915 https://doi.org/10.1257/jel.20151233 
155. Paul, (2006). A Survey of the Theoretical Economic Literature on Foreign Aid. Journal of The Crawford School of Public Policy, 20, 1. https://doi.org/10.1111/j.1467-8411.2006.00175.x

156. Pierce, R. (2008). Research Method in Politics: A Practical Guide. London: Sage Publication. Robinson, W. I. (2013). Promoting Polyarchy 20 Years Later. International Relations, 27(2), 228-234. https://doi.org/10.1177/0047117813489655a

157. Piva, P \& Dodd, R (2009). Where did all the aid go? an in-depth analysis of increased health aid flows over the past 10 years Bulletin of the World Health Organisation 87(12):930-939

158. Radelet, S (2004). Aid Effectiveness and the Millennium Development Goals Center for Global Development Working Paper No. 39.

159. Radelet, S. (2006). Primer on Foreign Aid. Center for Global Development Working Paper \#92.

160. Radelet, S., \& Levine, R., (2008). "Can We Build a Better Mousetrap? Three New Institutions Designed to Improve Aid Effectiveness", In Reinventing Foreign Aid, ed. Easterly, W., The MIT Press: Massachusetts, pp. 431-460.

160. Rajan, R. G., \& Subramanian, A. (2008). Aid and Growth: What Does the Cross-Country Evidence Really Show? Review of Economics and Statistics, 90, 643-666. https://doi.org/10.1162/rest.90.4.643

161. Rajan, R., \& Subramanian, A. (2005). Aid and Growth: What Does the Cross-Country Evidence Really Show? Working Paper 05/127. Washington, D.C.: International Monetary Fund.

162. Riddell, Roger (2007). Does Foreign Aid Really Work? Oxford: Oxford University Press.

163. Rodrik, D. (2007), “Getting institutions right”, in D. Rodrik, One Economics, Many Recipes: Globalization, Institutions and Economic Growth, Princeton University Press, Princeton, pp. 1-19.

164. Rondinelli, D.A. (1979) 'Administration of Integrated Rural Development Policy: The Politics of Agrarian Reform in Developing Countries’, World Politics 31.3: 389-416 https://doi.org/10.2307/2009995

165. Roodman, D. (2007). The Anarchy of Numbers: Aid, Development and Cross-Country Empirics. The World Bank Economic Review, 21(2), 255-277. https://doi.org/10.1093/wber/lhm004

166. Rosenstein-Rodan, P.N. (1943) 'Problems of Industrialisation of Eastern and South-Eastern Europe’, The Economic Journal 53.210-11: 202-11 https://doi.org/10.2307/2226317

167. Rostow, W. W. (1960): The Stages of Economics Growth: A non-Communist Manifesto London: Cambridge University Press.

168. Ruttan, V.W. (1984) 'Integrated Rural Development: A Historical Perspective', World Development 12.4: 393-401 https://doi.org/10.1016/0305-750X(84)90017-2

169. Sachs, J. (2005). The end of poverty. Economic possibilities for our time. New York: Penguin Press. 170. Sachs, J. D. (2005). The End of Poverty: Economic Possibilities for Our Time. New York: Penguin Books.

171. Sachs, J. D. (2014, January 21). The Case for Aid . Retrieved from Foreign Policy Website: http://www.foreignpolicy.com/articles/2014/01/21/the_case_for_aid.

172. Selaya, P., \& Thiele, R. (2010). Aid and Sectoral Growth: Evidence from Panel Data. Journal of Development Studies, 46(10), 1749-1766. https://doi.org/10.1080/00220388.2010.492856

173. Sanubi, F. A. (2011).The science of politics: An introductory methodological and statistical approach. Ibadan, Nigeria: Ibadan University Press.

174. Stiglitz, J. E. (2002). Globalization and its Discontents. New York: W.W. Norton.

175. Svensson, J. (1999). Aid and Growth: Does Democracy Matter? Economics \& Politics, 11(3), 275297. https://doi.org/10.1111/1468-0343.00062

176. Svensson, Lars E.O. (2009), "Evaluating Monetary Policy”, in Koenig, Evan, and Robert Leeson, eds., From the Great Moderation to the Great Deviation: A Round-Trip Journey Based on the Work of John B. Taylor, forthcoming, www.larseosvensson.net.

177. Timi, A.S (2016). International Organizations.Activities in Rural Areas. Report for the United Nations Development Programmes, Zurich: Switzerland

178. Todaro MP, Smith SC (2003) Economic development. Parson Addison Wesley, Harlow (Benn, 2004:8).

179. Thomas, A. (2004), The Study of Development. Paper prepared for DSA Annual Conference, 6 November, Church House, London.

180. Trumbull, W.N \& Wall, H. (1994). Estimating Aid-Allocation Criteria with Panel Data William N Trumbull and Howard Wall Economic Journal, 104, 425, 876-82. https://doi.org/10.2307/2234981

181. Ukaogo, V. (2008). Resource rights agitations and the "new forms of conflict ${ }^{\text {te }}$ in the Niger Delta, 1999-2008. Lagos Historical Review 8(1 ), 91-11 
182. Umaru, H. (2012).. Effect of Inflation on the Growth and Development of the Nigerian Economy (An Empirical Analysis) International Journal of Business and Social Science.

183. UNDP. (2006). Niger Delta Human Development Report UNDP Abuja.

184. UNDP. (2011). Country Office contributions 2011-2012 from Benin, Burundi, Chad, Côted 'Ivoire, DRC, Ethiopia, Ghana, Guinea,, Kenya, Lesotho, Malawi, Mozambique, Niger, Nigeria, Sierra Leone, Tanzania and Togo

185. Uvin, P. (2004). From the right to development to the rights-based approach: how human rights' entered development. Development in Practice.. 17, 4-5, 597-606. https://doi.org/10.1080/09614520701469617

186. Wane, W. (2004).The Quality of Foreign Aid: Country Selectivity or Donor Incentives? World Bank Policy Research Working Paper No. 3325. Washington, DC, USA: World Bank.

187. Werker, E., Ahmed, F. Z., \& Cohen, C. (2009). How is Foreign Aid Spent? Evidence from a Natural Experiment. American Economic Journal: Macroeconomics, 1(2), 225-244. https://doi.org/10.1257/mac.1.2.225

188. Whitaker, M.T (2006). The impact of foreign aid on economic growth. Bachelor of Arts in Economics Thesis Submitted to the Economics Faculty McCauley College of Liberal Arts Duquesne University Pittsburgh, Pennsylvania

189. Wilson, J. Q. (2000). Bureaucracy: What Government Agencies Do and Why They Do It. New York: Basic Books.

190. World Bank (2003), World Development Report 2004: Making Services Work for Poor People, World Bank, Washington, DC, https://openknowledge.worldbank.org/handle/10986/5986.

191. World Bank (2014), The Center Cannot Hold: Patterns of Polarization in Nigeria, Accessed 20 July

2018

192. World Development Indicators: Peru. Washington, DC: Author [cited May 11, 2011]. Available from http://data.worldbank.org/country/peru.

193. World Health Organization Maximizing Positive Synergies Collaborative Group. (2009.). An assessment of interactions between global health initiatives and country health systems. Lancet, 373, 21372169. https://doi.org/10.1016/S0140-6736(09)60919-3

194. World Health Organization (2010), Programmes and projects: Water sanitation and Health. Printable version. Creative Commons Attribution - Non Commercial - No Derivatives 4.0 International License. 